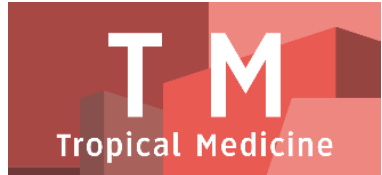

PAPER - OPEN ACCESS

\title{
Uji Aktivitas Ekstrak Pericarp Kulit Buah Manggis Terpurifikasi Dalam Penyembuhan Luka Eksisi
}

\author{
Author : Dira \\ DOI $\quad: 10.32734 /$ tm.v1i3.278 \\ Electronic ISSN : 2623-0542 \\ Print ISSN :2623-0550
}

Volume 1 Issue 3 - 2018 TALENTA Conference Series: Tropical Medicine (TM)

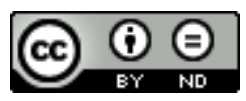

This work is licensed under a Creative Commons Attribution-NoDerivatives 4.0 International License.

Published under licence by TALENTA Publisher, Universitas Sumatera Utara
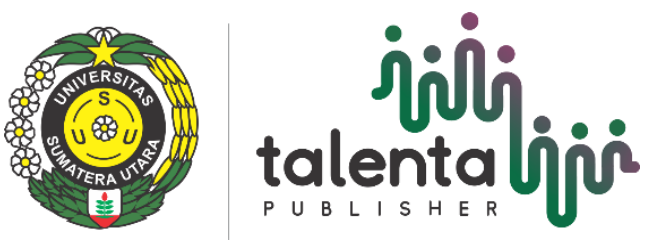


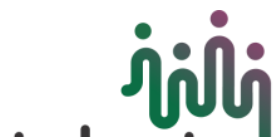 talentaliọi TALENTA Conference Series \\ Available online at https://talentaconfseries.usu.ac.id

\section{Uji Aktivitas Ekstrak Pericarp Kulit Buah Manggis Terpurifikasi Dalam Penyembuhan Luka Eksisi}

\author{
Dira $^{\mathrm{a}^{*}}$, Yanuarista, Ria Afrianti \\ ${ }^{a}$ Sekolah Tinggi Farmasi Indonesia Yayasan Perintis Padang \\ dira06139060@yahoo.com
}

\begin{abstract}
Abstrak
Alfa mangostin memiliki berbagai macam bioaktivitas dan merupakan major compound dalam eksrak kulit manggis (Garcinia mangostana L.), alfa mangostin memiliki aktivitas sebagai antioksidan, antiinflamasi dan antibakteri sehingga berperan dalam proses penyembuhan luka. Penelitian ini bertujuan untuk mengamati aktivitas ekstrak pericarp kulit buah manggis terpurifikasi yang mengandung $\geq 90 \%$ alfa-mangostin dalam penyembuhan luka eksisi pada mencit putih jantan secara in vivo. Paramater yang diukur adalah persentase penyembuhan luka eksisi, waktu epitelisasi dan kerapatan serabut kolagen. Mencit dibagi menjadi dua kelompok, dimana kelompok I merupakan kelompok kontrol negatif (-) yang hanya diberi sediaan suspensi Na CMC 1\%, sedangkan kelompok II merupakan kelompok perlakuan yang diberi sediaan suspensi ekstrak dengan konsentrasi $1 \%$. Pada hari ke-5, ke-10 dan ke-15 diukur persentase penyembuhan luka dan diamati waktu epitelisasi serta kerapatan serabut kolagen. Hasil penelitian dari persentase penyembuhan luka dan waktu epitelisasi yang dianalisa dengan uji General Linear Model Repeated Measures memberikan perbedaan secara nyata $(p<0,05)$, sedangkan untuk pengamatan serabut kolagen menunjukkan tidak ada perbedaan secara nyata $(\mathrm{p}>0,05)$ dan untuk waktu epitelisasi yang diuji menggunakan uji T Independent Sample memberikan perbedaan secara nyata $(\mathrm{p}<0,05)$, maka dapat disimpulkan bahwa ekstrak terpurifikasi dapat memberikan efek dalam penyembuhan luka eksisi pada mencit.
\end{abstract}

Kata Kunci : ekstrak pericarp kulit buah manggis terpurifikasi, alfa-mangostin, persentase penyembuhan luka, waktu epitelisasi dan kerapatan serabut kolagen.

\begin{abstract}
Alpha mangostin has a many kind of bioacivity and it is a major compoundin mangosteen ekstract (Garcinia mangostana L.). Alpha mangostin activities as antioxidant, antiinflamation,and antibacteria that functioned in the wound healing process. The research had been done to observe the activity of pericarp extract of purified mangosteen rind that containing $\geq 90 \%$ alphamangostin in healing excision wounds in male white mice with in vivo test. The parameters measured were percentage of wound healing excision, epithelial time and collagen fiber density. Mice were divided into two groups, where group I was a negative control (-), which was given only $1 \% \mathrm{Na}$ CMC suspension, whereas group II was treated with suspension of extract with $1 \%$ of concentration. On day $5^{\text {th }}, 10^{\text {th }}$ and $15^{\text {th }}$ were measured the percentage of wound healing and observed epithelial time and collagen fiber density. The results of the percentage of wound healing and epithelial time analyzed by General Linear Model Repeated Measures test showed significant differences $(\mathrm{p}<0.05)$, whereas for collagen fiber observation showed no significant difference ( $p>0.05)$ and for the epithelial time tested using Independent Sample $T$ test gives a significant difference ( $<<0.05)$, it can be concluded that pericarp extract of purified mangosteen rind can have an effect in healing excision wounds in mice.
\end{abstract}

Keywords : pericarp extract of purified mangosteen rind, alpha-mangostin, percentage of wound healing, epithelial time and collagen fiber density.

\section{Pendahuluan}

Indonesia dengan sumber alam hayati yang melimpah memiliki sekitar 30.000 spesies tumbuhan, kurang lebih 9.600 spesies diantaranya diketahui sebagai tanaman obat. Xanton merupakan senyawa kimia dengan manfaat antibakteri yang cukup kuat dan memiiki kemampuan memperlambat replikasi sel pada bakteri dan selain itu juga sebagai antioksidan yang tinggi dikulit buah manggis [1]. Senyawa yang paling utama terkandung dalam xanton 
adalah alfa mangostin. Penelitian membuktikan bahwa senyawa alfa mangostin yang diisolasi dari kulit buah manggis memiliki daya antimikroba terhadap Staphylococcus aureus dan Staphylococcus epidermidis [2]-[3].

Salah satu jenis luka adalah luka eksisi yaitu luka yang diakibatkan terpotongnya jaringan oleh goresan benda tajam [4]. Luka sembuh melalui reaksi radang, tujuan utamanya adalah membentuk jaringan parut yang keras, untuk menggabungkan bagian luka dan mengembalikan fungsinya [5]-[6].

Percepatan kesembuhan luka dapat dilakukan dengan cara mempertemukan kedua sisi luka, pemberian obat-obat seperti salep antibiotik atau dibalut dengan teknik tertentu seperti menggunakan hidrogel. Selain cara diatas, kesembuhan luka dapat pula ditunjang dengan menggunakan obat tradisional [7].

\section{Bahan dan Metode}

Alat yang digunakan adalah kertas perkamen, lumpang dan stamfer, timbangan digital, lemari pendingin, pipet tetes, pinset, beaker glass, spatel, gunting bedah, inkubator, mikrotom, teaching microscope, tissue processor, tissue embedding, object glass, block cassete dan cover glass (kaca penutup).

Bahan yang digunakan adalah mencit putih jantan, ekstrak pericarp kulit buah manggis yang telah terpurifikasi (mengandung $\geq 90 \%$ alfa-magostin), $\mathrm{Na} \mathrm{CMC}$, alkohol 30\%, 40\%, 50\%, 70\%, 80\%, 90\%, 95\% dan 96\%, aquadest, formalin 10\%, $\mathrm{HCl} 1 \%$, krim perontok bulu (Veet), kloroform, entellen, paraffin cair, pewarna HE, xylol.

Sampel yang digunakan dalam penelitian ini adalah ekstrak pericarp kulit buah manggis yang telah terpurifikasi (mengandung $\geq 90 \%$ alfa-magostin) yang diperoleh dari PT. Andalas Sitawa Fitolab. Sediaan uji yang digunakan dalam bentuk suspensi ekstrak dengan kosentrasi $1 \%$ dalam Na CMC $1 \%$.

Hewan percobaan yang digunakan mencit putih jantan sebanyak 18 ekor yang berumur 2-3 bulan dengan berat 20-25 gram yang dibagi menjadi 2 kelompok, masing-masing kelompok terdiri dari 9 ekor. Sebelum digunakan mencit terlebih dahulu diaklimatisasi selama 7 hari.

Kelompok I adalah Kelompok yang dioleskan Na CMC 1\% (kontrol) sedangkan Kelompok II adalah Kelompok yang dioleskan ekstrak pericarp kulit buah manggis yang telah terpurifikasi (mengandung $\geq 90 \%$ alfa-magostin) dengan konsentrasi 1\% dalam suspensi (perlakuan). Perlakuan diberikan 1 kali sehari sebanyak 0,3 $\mathrm{ml}$ (6 tetes).

\subsection{Pembuatan Luka}

Bulu pada bagian punggung hewan dirontokkan menggunakan krim perontok bulu. Selanjutnya hewan dianestesi menggunakan kloroform. Bagian punggung yang telah dirontokkan bulunya dibersihkan dengan alkohol 70\%, selanjutnya dibuat luka berbentuk lingkaran dengan diameter $\pm 1 \mathrm{~cm}$, dengan cara mengangkat kulit mencit dengan pinset dan digunting dengan gunting bedah.

\subsection{Parameter Yang Diukur pada Penyembuhan Luka}

\subsubsection{Persentase Penyembuhan Luka}

Dicatat persentase penyembuhan luka pada hari ke-5, ke-10 dan ke15. Persentase penyembuhan luka dihitung dengan rumus:

$$
\frac{\text { luas daerah yang sembuh }}{\text { luas daerah luka awal }} \times 100 \%
$$

\subsubsection{Waktu Epitelisasi}

Waktu yang diperlukan untuk terbentuknya epitel baru yang sempurna menutupi daerah luka. Hal ini dicatat hari kepengelupasan jaringan keropeng dari luka tanpa meninggalkan sisa luka di area eksisi.

\subsubsection{Histopatologi}

Dilakukan pengamatan terhadap kerapatan serabut kolagen dari daerah luka. Dari tiap kelompok diambil 3 ekor mencit untuk di dekapitasi masing-masing pada hari ke-5, ke-10 dan ke-15. Sampel dari jaringan luka diambil 0,3 $\mathrm{cm}$ dari tepi luka awal dan dibuat sediaan histologi.

\subsection{Pembuatan Sediaan Histologis}


Preparat histologi dibuat dengan cara mengambil jaringan luka dan dilakukan proses fiksasi, dehidrasi, blearing, embedding, serta dilakukan pemotongan jaringan. Jaringan yang telah dipotong lalu diwarnai dengan HematoksilinEosin (HE) dan diamati dibawah mikroskop dan diberi skor berdasarkan kriteria:

0 : tidak tampak serabut kolagen.

1 : serabut kolagen menyebar tipis atau sedikit.

2 : serabut kolagen menyebar sedang atau tampak penyatuan.

3 : serabut kolagen menyebar banyak dan terikat sempurna.

Nilai yang didapat dari masing-masing parameter dihitung sebagai rata-rata lebih kurang standar deviasi (SD). Signifikansi dari perbedaan nilai rata-rata akibat perlakuan ini terhadap kelompok kontrol dianalisa menggunakan Uji General Linear Model Repeated Measures dan Uji T Independent Sample.

\section{Hasil dan Pembahasan}

Sampel yang digunakan mengandung $\geq 90 \%$ alfa-mangostin. Senyawa alfa mangostin merupakan derivat xanton yang memiliki rumus molekul $\mathrm{C}_{24} \mathrm{H}_{26} \mathrm{O}_{6}$ dan memiliki aktivitas sebagai antioksidan, antiinflamasi, antimalaria, antitumor dan lain-lain [8,9].

Penelitian ini menggunakan konsentrasi ekstrak 1\% karena sebelumnya telah dilakukan penelitian dengan menggunakan 3 perbandingan konsentrasi antara lain: 0,1\%, 1\% dan 5\%, dimana konsentrasi $1 \%$ memberikan hasil yang cukup baik terhadap penyembuhan luka [10].

Pada proses penyembuhan luka ada 3 fase yang berperan penting dalam proses penyembuhan luka yaitu fase inflamasi, fase proliferasi dan fase maturasi [11].. Fase inflamasi berlangsung sejak terjadinya luka sampai hari ke-5. Pada fase ini terjadi reaksi radang dengan gejala klinis berupa kemerahan dan pembengkakan. Fase proliferasi berlangsung dari akhir proses inflamasi sampai hari ke-13. Pada fase ini luka dipenuhi sel radang, fibroblast dan kolagen. Fibroblast adalah sel yang paling banyak terdapat dalam jaringan ikat yang berperan membentuk dan meletakkan serat-serat dalam matrik, terutama serat kolagen [12]. Kolagen secara normal ditemukan menghubungkan jaringan. Kolagen adalah sel yang paling penting pada penyembuhan fase inflamasi dan fase proliferasi [13]. Fase maturasi, berlangsung setelah akhir fase proliferasi pada hari ke-14. Pada fase ini terjadi proses pematangan yang terdiri atas penyerapan kembali jaringan yang berlebih, pengerutan sesuai dengan gravitasi dan penguatan jaringan yang baru terbentuk [14]. Secara visual dilakukan pengamatan persentase penyembuhan luka (Tabel 1).

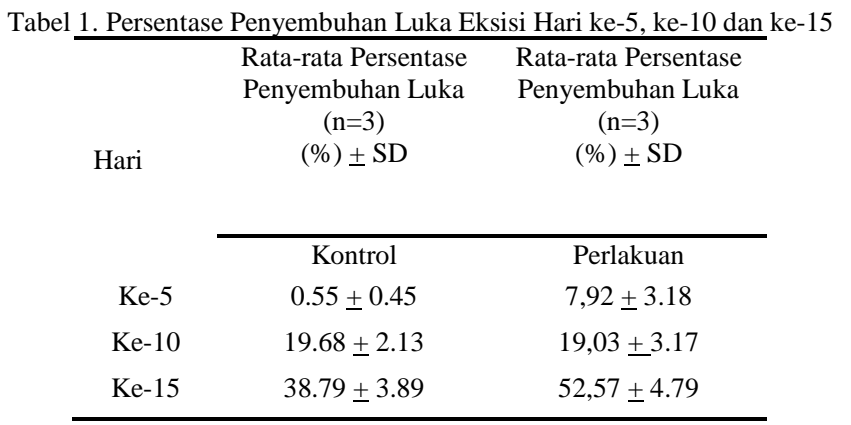
2.

Pengamatan waktu epitelisasi untuk kelompok I (kontrol negatif) dan kelompok II (perlakuan) terlihat pada Tabel

\begin{tabular}{cc}
\multicolumn{2}{c}{ Tabel 2. Waktu Epitelisasi } \\
\hline \multirow{3}{*}{ Relompok } & $\begin{array}{c}\text { Rata-rata }(\mathrm{n}=3) \\
\text { Waktu Epitelisasi } \pm \\
\text { SD } \\
\text { (Hari) }\end{array}$ \\
\hline Kontrol & $14.67 \pm 0.58$ \\
Perlakuan & $11.67 \pm 0.58$
\end{tabular}

Kerapatan serabut kolagen dinyatakan dalam skor (Tabel 3). Kelompok I (kontrol negatif) menunjukkan bahwa pada hari ke-5 jaringan luka memiliki kerapatan serabut kolagen masih tipis (skor + ) dan masih terlihat jaringan yang belum terbentuk sempurna. Pada hari ke-15 jaringan luka telah memiliki kerapatan yang cukup baik dengan skor (++) sampai dengan skor (+++) pada beberapa mencit dan jaringan mulai terbentuk secara perlahan mendekati jaringan normal pada umumnya (Gambar 1). 
Tabel 3. Hasil Pemeriksaan Kerapatan Serabut Kolagen Hewan Percobaan Rata-rata skor $(n=3) \pm$ SD

Hari ke-5

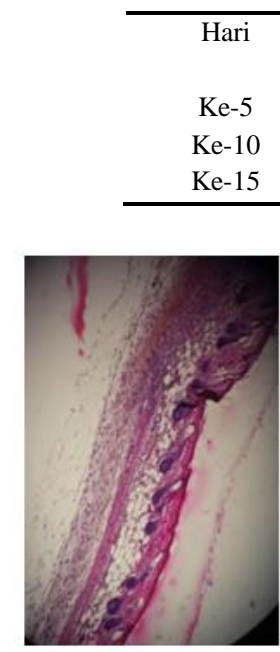

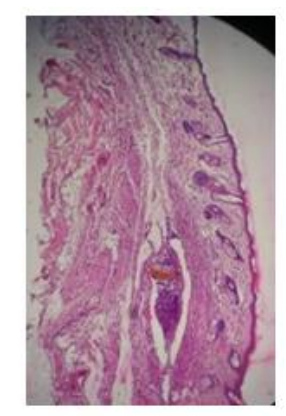

Hari ke-10

$$
2 \pm 0
$$$$
2.67 \pm 0.58
$$$$
3 \pm 0
$$

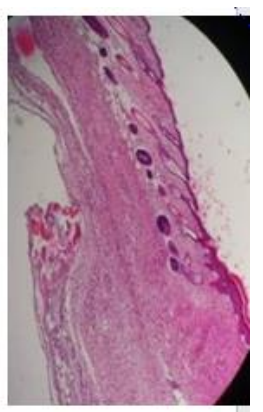

Hari ke-15

Gambar 1. Foto Kerapatan Serabut Kolagen Kelompok 1 (Kontrol Negatif)

Hasil pengamatan pada kelompok II (perlakuan) menunjukkan bahwa pada hari ke-5 kerapatan serabut kolagen sedang (skor ++), masih terlihat luka yang belum sembuh sepenuhnya. Pada hari ke-15 secara visual hampir terlihat bahwa mencit hampir sembuh sempurna dan secara histologi kerapatan serabut kolagen padat (skor +++) (Gambar 2).

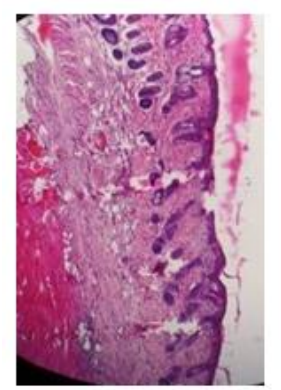

Hari ke-5

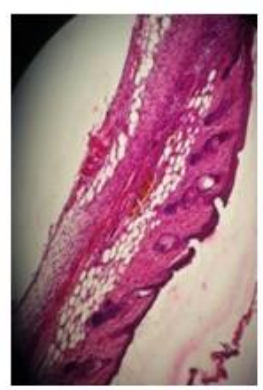

Hari ke-10

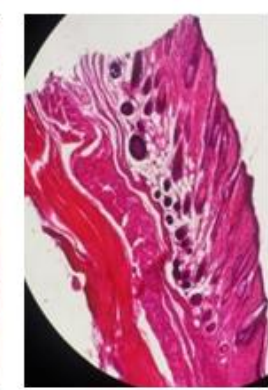

Hari ke-15

Gambar 2. Foto Kerapatan Serabut Kolagen Kelompok 2 (Perlakuan)

Data yang diperoleh dari penelitian ini selanjutnya diolah secara statistik menggunakan General Linear Model Repeated Measure (GLM) dan uji T Independent Sample. Hasil analisa menunjukkan bahwa untuk paramater persentase penyembuhan luka eksisi memberikan perbedaan yang cukup signifikan $(\mathrm{p}<0,05)$ sedangkan untuk pengamatan serabut kolagen pada analisa ini tidak menunjukkan perbedaan yang nyata $(\mathrm{p}>0,05)$, sedangkan berdasarkan uji $\mathrm{T}$ untuk parameter waktu epitelisasi hasilnya menunjukkan perbedaan yang nyata $(\mathrm{p}<0,05)$.

\section{Kesimpulan}

Dari hasil penelitian didapatkan bahwa ekstrak pericarp kulit buah manggis yang telah terpurifikasi (mengandung $\geq 90 \%$ alfa-magostin) dalam penyembuhan luka eksisi pada mencit putih jantan dengan konsentrasi $1 \%$, dengan parameter persentase penyembuhan luka, waktu epitelisasi dan kerapatan serabut kolagen menggunakan uji General Linear Model Repeated Measures memberikan perbedaan secara nyata $(\mathrm{p}<0,05)$ untuk hasil persentase penyembuhan luka, sementara untuk hasil kerapatan serabut kolagen menunjukkan tidak ada perbedaan secara nyata 
$(\mathrm{p}>0,05)$ dan berdasarkan uji $\mathrm{T}$ untuk waktu epitelisasi menunjukkan perbedaan secara nyata $(\mathrm{p}<0,05)$, dari ketiga parameter tersebut dapat disimpulkan bahwa pemberian senyawa alfa mangostin dapat mempercepat waktu sembuhnya luka dengan terbentuknya epitel baru pada daerah luka yang lebih cepat.

\section{Daftar Pustaka}

[1] Joffrion, D., E. 2007. Mangosteen the X factor. USA: Cross Oaks Chiropractic Health and Pain Relief Center.

[2] Linuma, M., Tosa, H., Tanaka, T., Asai, F., Kobayashi, Y., Shimano, and R., Miyuchi, K. 1996. Antibacterial Activity of Xantones From Guittiferaeous Plants Against Methicilin-Resistant Staphylococcus aureus. J. Pharm. Pharmacol 48(8): 861-865.

[3] Astika, AT. 2010. Uji Aktivitas Antibakteri Senyawa Alfa Mangostin Hasil Isolasi Kulit Buah Manggis (Garcinia mangostana L.) Terhadap Staphylococcus epidermidis (Skripsi). Surakarta: UMS.

[4] Singer dan Dagum. 2008. Proses Penyembuhan Luka. Bandung: Salemba.

[5] Tambayong, Jan. 2000. Patofisiologi Untuk Keperawatan. Jakarta: Buku Kedokteran EGC.

[6] Sabiston, D., C. 1995. Buku Ajar Bedah. Jakarta: Buku Kedokteran EGC.

[7] Suwiti, N., K. 2010. Deteksi Histologik Kesembuhan Luka Pada Kulit Pasca Pemberian Daun Mengkudu (Morinda citrifolia linn.). Bali: Buletin Veteriner Udayana.

[8] Sudarsono, D., Gunawan, S., Wahyuono, I., A., Donatus, danPurnomo. 2002. Tumbuhan Obat II, Hasil Penelitian,Sifat-Sifat, dan Penggunaan. Yogyakarta: Pusat StudiObat Tradisional UGM.

[9] Chaverri, JP, Noemi Cardenas-Rodriguez, Marisol Orozco-Ibarra, Jazmin M., and Perez-Rojas. 2008. Medicinal properties of mangosteen (Garcinia mangostana L.). Food and Chemical Toxicology 46: 3227-3239.

[10] Ilhami, R, Sanubari RT, dan Dira. 2017. Pemerikisaan Kadar Hidroksiprolin dan Uji Aktivitas Alfa-mangostin terhadap Penyembuhan Luka pada Tikus Putih Jantan. (Skripsi) Padang: STIFI Perintis Padang.

[11] Arisanty, IP. 2011. Konsep Dasar Manajemen Perawatan Luka. Jakarta: Buku Kedokteran EGC.

[12] Junqueira, L., C., \& Carnerio, J. 2007. Histologi Dasar Teks dan Atlas, edisi 10. Jakarta: Buku Kedokteran EGC.

[13] Black, JM \& Jacobs, EM. 1997. Medical Surgical Nursing Clinical Management For Continuity Of Care (5 ${ }^{\text {th }}$ ed). Philadelphia: Saunders Company. 